\title{
PKM MENGGALI POTENSI, MEMOTIVASI DAN MENGARAHKAN GENERASI MUDA MENYONGSONG DUNIA KERJA
}

\author{
${ }^{1}$ Suwanto, ${ }^{2}$ Priehadi Dhasa Eka, ${ }^{3}$ Randhy Agusentoso \\ Dosen Fakultas Ekonomi Universitas Pamulang \\ Email : $\underline{1}$ dosen01813@unpam.ac.id
}

\begin{abstract}
ABSTRAK
Anggota karang taruna selain bisa langsung bekerja juga bisa melanjutkan ke jenjang pendidikan yang lebih tinggi yaitu perguruan tinggi namun memilih jurusan di perguruan tinggi tentunya menyesuaikan dengan minat dan kemampuan para anggota. Permasalahan yang sering terjadi adalah kurangnya pengetahuan para anggota tentang rencana kedepan sehingga banyak anggota karang taruna yang justru menjadi pengangguran, hal tersebut karena kurangnya pengetahuan tentang persiapan memasuki dunia kerja serta jika ingin kuliah kurangnya pengetahuan tentang jurusan yang akan diambil dan bagaimana memilih perguruan tinggi yang baik dan benar. Untuk menghadapi permasalahan tersebut perlu diberikan pengarahan kepada para anggota tentang persiapan memasuki dunia kerja atau kuliah.

Metode pengabdian yang dilakukan adalah metode ceramah sebanyak dua kali pertemuan dengan lima narasumber yang berbeda. Pertemuan pertama materi tentang bagaimana Mimpi dan Cita cita, Persiapan Memasuki Dunia Kerja, Biodata diri dan Surat Lamaran, Wawancara Lamaran Kerja , Mengenal Tipe Soal Psikotes serta cara memilih jurusan dan perguruan tinggi yang benar. Pertemuan kedua dengan melakukan praktek dari materi yang telah di berikan.

Dari kuesioner yang disebar memberikan hasil bahwa para anggota merasa puas dengan materi yang diberikan dan berharap menjadi agenda rutin di karang taruna sebelum para anggota menyelesaikan pendidikan.
\end{abstract}

\section{Kata Kunci : Cita Cita, Dunia Kerja, Surat Lamaran, Wawancara, Psikotes}

\section{PENDAHULUAN}

Karang taruna berperan positif dalam pertumbuhan ekonomi daerah, peran ini dapat dilacak dari tiga hal yaitu preferensi masyarakat, kapasitas bagi anggota karang taruna dimulai dari berpendidikan SMP, dan kemampuan Karang taruna dalam mencetak anggota yang berkualitas. Animo masyarakat terhadap karang taruna berkaitan dengan perkembangan karang taruna dan perkembangan karang taruna berkaitan dengan perkembangan anggotanya.

Kualitas anggota inilah yang menjadi penentu ekonomi daerah [1] . Sesuai laporan Bank Indonesia dalam Kajian Ekonomi Keuangan dan Regional Provinsi Jawa Barat pada Mei 2018 bahwa perekonomian provinsi 
Jawa Barat pada triwulan pertama 2018 tumbuh 5,47\% lebih tinggi disbanding pertumbuhan triwulan sebelumnya sebesar $3,57 \%$. Jumlah angkatan kerja per Februari 2018 tumbuh melambat sebesar 2,15\% sementara Indeks Pembangunan Manusia (IPM) Garut kembali mencatat pertumbuhan dan berada pada kategori tinggi. Kesiapan berkerja anggota karang taruna dipengaruhi oleh beberapa faktor diantaranya faktor pribadi para anggota dan lingkungan yang terdiri dari cita cita, lingkungan keluarga, kesehatan, kepribadian, bakat dan kemampuan para anggota. [2] Anggota karang taruna selain bisa langsung bekerja, juga bisa punya pilihan untuk melanjutkan ke jenjang Pendidikan lebih tinggi yaitu masuk perguruan tinggi. Memilih jurusan di perguruan tinggi tentunya dengan menyesuaikan dengan jurusan dan minat serta kemampuan.

Menurut Direktur yang membidangi karang taruna, Kementrian Pendidikan dan Kebudayaan (Kemdikbud) baru 10 persen anggota karang taruna terserap Perguruan Tinggi, hal ini dikarenakan juga oleh kondisi ekonomi orang tua para anggota karena semakin tinggi kondisi sosial ekonomi orang maka motivasi melanjutkan pendidikan ke perguruan tinggi akan semakin

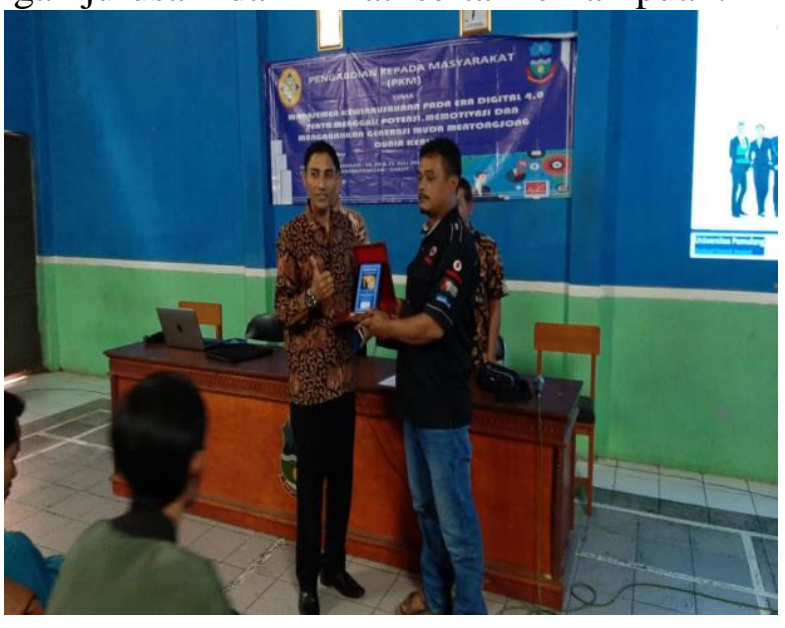
tinggi [3] . Minat para anggota masuk perguruan tinggi dipengaruhi oleh motivasi, prestasi belajar, status sosial ekonomi orang tua dan lingkungan teman sebaya dari para anggota [4]. Anggota karang taruna yang disiapkan untuk siap masuk dunia kerja atau membuka lapangan pekerjaan sendiri, untuk itu para anggota karang taruna diwajibkan mengikuti praktek kerja industri dimana pendidikan dilaksanakan dilapangan atau diluar kelas dalam bentuk praktek langsung ke dunia kerja atau dunia industri.

Hasil penelitian sebelumnya membuktikan bahwa semakin baik praktek kerja lapangan/industri akan semakin meningkatkan kesiapan kerja para anggota [5]. Pengalam praktek kerja industri berpengaruh positif terhadap kesiapan kerja para anggota [6], demikian juga hasil penelitian [7] dan [8] .karang taruna KarangPawitan Garut adalah Karang taruna di Garut yang beralamat di Rt.02 Rw.05 Kampung Gunamekar desa karangpawitan Garut ini didirikan pada tahun 2006 dengan program kepemudaan, merupakan salah satu kompetensi keahlian yang dimiliki karang taruna KarangPawitan Garut, dimana kompetensi keahlian tersebut masuk dalam jurusan bisnis dan manajemen, yaitu kompetensi keahlian yang memberi bekal pengetahuan, keterampilan dan sikap. Kesiapan para anggota Karang taruna KarangPawitan dalam memasuki dunia kerja juga dengan melakukan praktek kerja industri yang sebagian besar dilaksanakan di kota Garut, karena kota Garut 
merupakan kota industri, sehingga memudahkan para anggota karang taruna KarangPawitan terutama berpendidikan SMA/SMK/Karang taruna Kejuruan dalam mencari tempat praktek industri, praktek kerja tersebut dilaksanakan

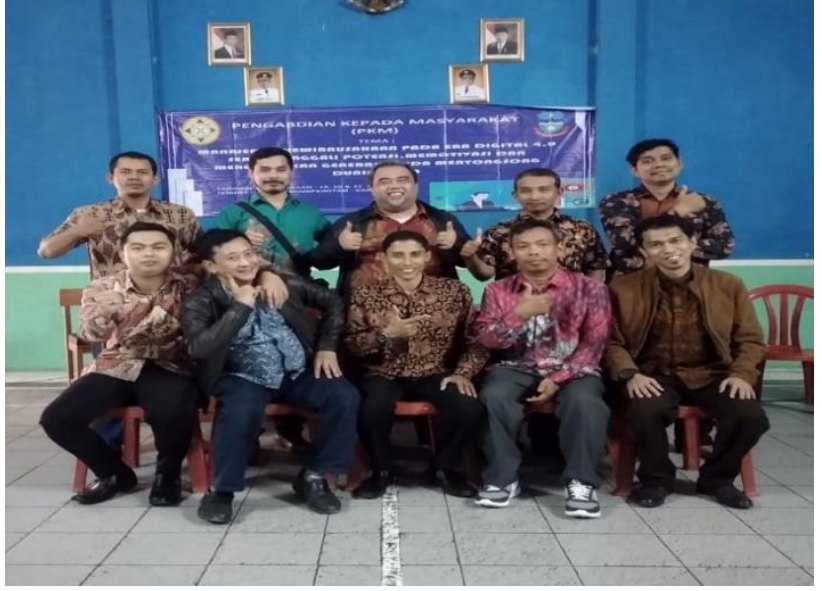
selama lebih kurang 1 semester (6 bulan). Gambar 1 karang taruna KarangPawitan Garut Para anggota karang taruna KarangPawitan SMA/SMK/Karang SMA/SMK/Karang taruna Kejuruan lainnya masih terlihat kurang mendapatkan materi tentang persiapan memasuki dunia kerja atau kuliah, dimana para anggota hanya mendapatkan materi tentang bagaimana cara membuat surat lamaran yang dipelajari para anggota pada mata pelajaran Bahasa Indonesia, namun belum diberikan pembekalan tentang apa yang akan dilakukan para anggota kedepan setelah tamat karang taruna, semisal para anggota ingin bekerja di perusahaan, belum diberikan pembekalan tentang bagaimana cara mencari atau mendapatkan lowongan pekerjaan dengan cepat, bagaimana membuat surat lamaran atau daftar riwayat hidup yang baik, serta bagaimana teknik wawancara kerja yang baik. Jika orang tua para anggota mampu secara keuangan, kemudian para anggota ingin melanjutkan ke perguruan tinggi, masih kurangnya pengetahuan para anggota tentang memilih perguruan tinggi yang baik dan benar juga jurusan yang dipilih, dimana para anggota karang taruna yang berpendidikan SMA/SMK/Karang taruna Kejuruan, setelah masuk perguruan tinggi tapi tidak memilih melanjutkan ke jurusan sesuai pendidikan sebelumnya juga namun memilih jurusan lain. Adapun tujuan dari materi pembekalan memasuki dunia kerja atau kuliah ini adalah memberikan pembekalan dan pemahaman kepada para anggota tentang bagaimana cara menentukan pilihan setelah tamat karang taruna, apakah akan bekerja atau melanjutkan pendidikan keperguruan tinggi

\section{METODE PELAKSANAAN KEGIATAN}

Pembinaan dengan hasil sebagai berikut:

1. Sebelum tim PKM yang merupakan dosen pada program studi Manajemen Universitas Pamulang turun untuk melaksanakan kegiatan pengabdian kepada masyarakat ini, tim PKM telah terlebih dahulu melakukan survey atau pengamatan pendahuluan dimana kegiatan survei ini dilaksanakan pada tanggal 07 Juli 2018. Survei yang dilakukan oleh tim PKM tersebut meliputi hal-hal sebagai berikut: 
Survey tempat/lokasi pelaksanaan pengabdian kepada masyarakat yang akan diadakan oleh team PKM sesuai tema PKM yaitu; Menggali Potensi, Memotivasi dan Mengarahkan Generasi Muda Menyongsong Dunia Kerja

2. Silaturahmi dengan pihak karang taruna dalam hal ini diwakili oleh Ketua karang taruna KarangPawitan Garut sdr Ifan Ahmad Sopian. Pada kesempatan itu tim PKM mendengarkan keluhan-keluhan atau masukan bimbingan apa yang diinginkan dan dibutuhkan para anggota karang taruna selama ini. Pada kesempatan itu juga tim PKM mengajukan atau menawarkan diri untuk melakukan pengabdian kepada masyarakat di lingkungan karang taruna tersebut dengan mengadakan pembinaan pembekalan Memasuki Dunia Kerja Atau Kuliah dengan memberikan materi dan pelatihan salah satu formasi kemajuan teknologi informasi sekarang dalam kegiatan bisnis dan laporan keuangan yang sangat banyak di butuhkan oleh perusahan.

3. Sebelumnya tim PKM juga melakukan komunikasi dengan beberapa alumni karang taruna KarangPawitan Garut, dimana menyatakan bahwa selama karang taruna sampai dengan selesai, tidak mendapatkan pembekalan untuk memasuki dunia kerja atau kuliah, sehingga alumni mengalami sedikit kendala sewaktu sudah selesai karang taruna, seperti bagaimana memilih perguruan tinggi yang baik dan benar, bagaimana teknik wawancara yang baik serta bagaimana melihat lowongan lowongan kerja yang ada.

4. Seluruh tim PKM menyiapkan bahan dan materi yang akan disampaikan pada tahap pelaksanaan, dimana seluruh tim PKM yang terdiri dari 5 orang yaitu 5 dosen dan merupakan narasumber dari kegiatan pengabdian kepada masyarakat dengan tema pembinaan sasaran anggota karang taruna. Tim PKM menyepakati untuk membagi materi menjadi dua kelompok yaitu pembekalan memasuki dunia kerja dan kuliah serta beberapa materi penunjang lainnya. Tim PKM sepakat untuk mempersiapkan materi presentasi yang dibagi menjadi 5 dengan materi pengantar Mimpi dan Cita Cita, persiapan menghadapi dunia kerja, membuat Surat Lamaran Kerja menyusun Bio Data, materi menghadapi Wawancara dan materi persiapan menghadapi Soal Psykotes yang nantinya akan disampaikan pada pertemuan pertama,kemudian pada pertemuan kedua pelatihan dengan materi praktek serta teori .

5. Menyepakati penentuan jadwal pembinaan dengan para anggota KARANG TARUNA KarangPawitan Garut dan Universitas Pamulang mengingat untuk pelatihan membutuhkan fasilitas itu sendiri dan semua fasilitas yang tersedia oleh Universitas Pamulang, dan karena jadwal belajar para anggota KARANG TARUNA KarangPawitan Garut yang hanya belajar sampai dengan hari Jumat, maka disepakati untuk melaksanakan pengabdian pada hari Sabtudengan tetap didampingi oleh pihak tokoh masyarakat dan lingkungan setempat 
6. Tim PKM menyerahkan surat izin pelaksanaan kegiatan pengabdian kepada masyarakat yang dikeluarkan secara resmi oleh Universitas Pamulang dan juga menyerahkan proposal pengadaan kegiatan pembinaan yang ditujukan bagi pihak pimpinan dalam hal ini Ketua KARANG TARUNA KarangPawitan Garut. Surat izin dan laporan ini merupakan syarat dari pelaksanaan kegiatan pengabdian kepada masyarakat. Tim PKM mempersiapkan bahan-bahan dan materi sebelum pelaksanaan kegiatan sesuai dengan tugas masing-masing seperti mempersiapkan absensi kehadiran, dokumentasi, konsumsi, bahan-bahan seminar kit, serta sertifikat yang akan diberikan kepada peserta kegiatan.

\section{HASIL DAN PEMBAHASAN}

Hasil dari kegiatan pembinaan ini adalah menunjukkan bahwa para peserta anggota karang taruna KarangPawitan Garut paham bagaimana mempersiapkan diri menghadapi dunia kerja dan bagaimana menggunakan program komputer akuntansi untuk membuat atau mengelola laporan keuangan perusahaan yang bisa menjadi modal mereka untuk melamar pekerjaan sesuai dengan kompetensi yang mereka miliki.

Pelaksanaan Pengabdian Kepada Masyarakat dengan Pembinaan Sasaran anggota karang taruna ini tema tentang pembinaan Pembekalan Memasuki Dunia Kerja Atau Kuliah. Pembinaan tersebut terdiri dari materi pokok yang disampaikan oleh Tim PKM yaitu Pembekalan Memasuki Dunia Kampus dan Pembekalan Memasuki Dunia Kerja yang disampaikan pada pertemuan pertama tanggal 20 Juli 2019 dimana pada pembekalan memasuki dunia kampus dijelaskan tentang kenapa kuliah itu penting, jika kuliah masih memungkinkan untuk bisa sambil bekerja atau berwirausaha untuk memanfaatkan waktu yang ada dan melakukan time management, dalam materi ini juga disampaikan bagaimana memilih perguruan tinggi yang baik dan benar serta memilih jurusan yang benar. Materi kedua pada pertemuan pertama disampaikan tentang bagaimana jika setelah selesai karang taruna ingin langsung bekerja, apa saja yang harus dipersiapkan untuk bekal menghadapi dunia kerja, seperti teknik wawancara yang benar, bagaimana mencari dan mendapatkan lowongan kerja serta jika memilih ingin berwirausaha, apa saja yang harus disiapkan. Pelaksanaan pengabdian pada pertemuan kedua berisi tentang praktek atas materi yang telah di pelajari kupas tuntas terkait hal hal sebagai berikut :

a. Isu terkini terkait jumlah lulusan dan pengangguran serta menangkap peluang

b. Menentukan tujuan dan atau cita cita usai lulusan smk sesuai dengan potensi yang dimiliki.

c. Mencari prospek sebagai tujuan tempat bekerja usai lulus smk

d. Menyiapkan berkas berkas dokumen sebelum memasuki dunia kerja 
e. Mengenal tipe tipe soal psikotest \& memecahkannya

f. Teknik menghadapi wawancara kerja

g. Memilih kampus yang tepat sesuai dengan situasi dan kondisi pribadi siswa

Penjabaran kegiatan yang diberikan dalam kegiatan pembinaan ini adalah sebagai berikut :

1. Menjelaskan, memaparkan dan memperkenalkan cara cara yang baik didalam mengapresiasikan diri didalam mewujudkan Mimpi dan Cita Cita sesuai dengan kemampuan dan harapan. Menjelaskan apakah itu Mimpi yang ada serta kemampuan diri di dalam megejawantahkan dalam usaha pribadi sesuai pada pemahaman diri terhadap mimpi yang akan di raihnya. Menjelaskan apakah itu Cita - Cita dan bagaimana mewujudkannya bila di sesuaikan dengan Cita Cita yang dituju sebagai tujuan hidup setiap insan pribadi dari setiap anggota karang ataruna karang pawitan desa gunamekar garut jawa barat.

2. Menjelaskan bagaimana persiapan memasuki dunia kerja. Era kemajuan jaman menuntut pola berfikir secara keras yang akan mendorong setiap pekerja untuk berfikir praktris dan penuh inovatif yang dapat memberikan kecepatan pelayanan bekerja serta memberikan kontribusi dalam memajukan unit unit usaha pada suatu perusahaan. Bagaimana suatu ketrampilan dari calon pekerja didalam menyelesaikan pekerjaan pada satu di satu perusahaan. Bagaimana suatu ketrampilan itu memiliki kemampuan dalam daya saing antar satu perusahaan dengan suatu perusahaan lainnya.

3. Memberikan pelatihan dasar pada para anggota KARANG TARUNA KarangPawitan Garut Kota Kotamadya Garut propinsi Jawa Barat tentang cara membuat Bio Data diri dan surat Lamaran yang dapat dengan jelas memberikan informasi tentang ke ahlian serta ketrampilan pemohon kerja hingga dapat memenuhi permintaan dari perusahaan pembuat lowongan kerja. Dengan kempuan ini diharapkan peserta pelatihan dapat mengerti maksud dari pengumuman penerimaan lowongan kerja serta dapat mencoba juga membuat biodata juga surat lamaran kerja kepada satu perusahaan.

4. Memberikan pendampingan pada peserta anggota KARANG TARUNA Karang Pawitan, Kota Kotamadya Garut propinsi Jawa Barat dalam praktek tanya jawab Wawancara Lamaran. Diharapkan bahwa peserta dapat mengerti maksuda dan arti suatu wawancara apa yang di gali oleh satu perusahaan pada wawancara tersebut. Dengan demikinan diharapkan peserta latihan akan terbiasa dan tidak demam panggung atau grogi saat wawancara nantinya karena sudah mengerti apa itu wawancara.

5. Melakukan pemantauan atau monitoring pada peserta anggota KARANG TARUNA KarangPawitan, desa Gunamekar Kotamadya Garut propinsi Jawa Barat terhadap kemampuan penguasaan mereka pada Soal soal Psikotest yang telah diajarkan dalam pelatihan dan pembinaan ini. Diharapkan dengan 
ini para peserta akan dapat mengenal tipe tipe soal psikotest dengan baik dan dapat menjalan test psikotest sebaik baiknya.

6. Melakukan evaluasi dan penilaian terhadap para peserta anggota KARANG TARUNA KarangPawitan, desa Gunamekar Kotamadya Garut propinsi Jawa Barat Kotamadya yang mana mereka di waktu sebelumnya telah diberikan pengarahan, pemaparan, pelatihan, pendampingan serta pemantauan dalam peningkatan kemampuan mereka dalam penguasaan mereka terhadap membuat surat lamaran, test psikotes serta wawancara yang telah diajarkan dalam pelatihan dan pembinaan ini.

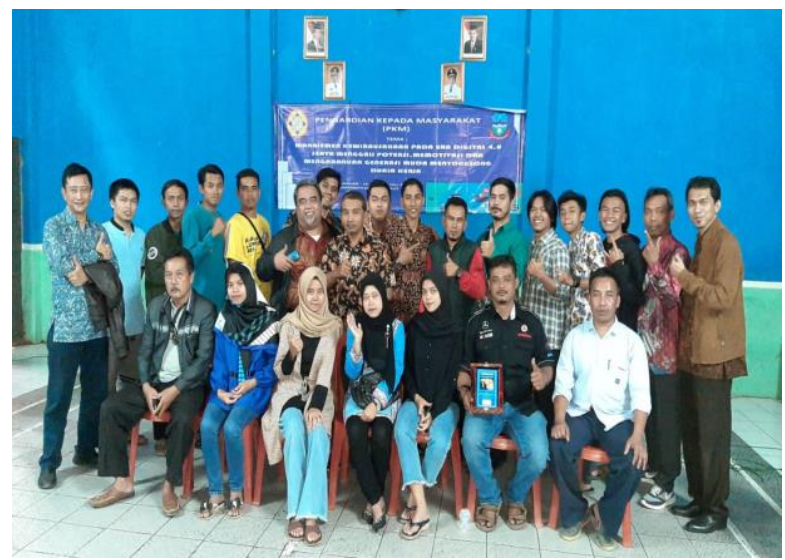

\section{KESIMPULAN DAN SARAN}

Pelaksanaan kegiatan ini diharapkan bisa menjadi agenda rutin bagi pihak karang taruna agar para anggota mendapatkan pembekalan setelah anggota karang taruna menjelang tamat sekolah, karena keterbatasan waktu dan tempat, belum semua para anggota KARANG TARUNA KarangPawitan mendapatkan pembekalan tersebut, diharapkan kedepannya kegiatan ini bisa diberikan kepada seluruh para anggota terutamanya para anggota karang taruna yang masih di jenjang pendidikan sekolah serta usia memasuki dunia kerja.

\section{DAFTAR PUSTAKA}

Direktorat Bina Karang Taruna.2005.Buku pedoman dasar karang taruna. Departemen Sosial. R.I

Keputusan Temu Karya IV Karang Taruna Indonesia Tahun 2001 (TKN IV KT Indonesia 2001) Nomor: 005/TKN.IV/2001

Karang Taruna Indonesia Tahun 2001 (Tkn IV KT Indonesia 2001) di Medan

Keputusan Menteri Sosial Nomor: 11/HUK/1998 : Peraturan menteri sosial republic Indonesia nomor: 77/HUK/2010. Tentang Pedoman Dasar Karang Taruna.

Peraturan Menteri Sosial RI Nomor 83/HUK/2005 tentang Pedoman Dasar Karang Taruna (Pengganti Keputusan Menteri Sosial RI Nomor 11/HUK/1988). Undang-Undang RI Nomor 6 Tahun 2014 tentang Desa [5]

Salim segaf Al zufri,MA. (2010), Tentang Pedoman Dasar Karang Taruna. Di Jakarta

Sunarsi, D., \& Asmalah, L. (2018). Pelatihan Manajemen Pengembangan Diri Bagi Penerima Beasiswa RZIS UGM Dan Dompet Shalahuddin Jogjakarta. Jurnal Pengabdian Dharma Laksana, 1(1).

Undang - Undang Nomor 40 Tahun 2009.Tentang Kepemudaan 